\title{
TEOLOGI PEREMPUAN: MENYEJAJARKAN ATAU MENYATUKAN ?
}

Saiful Amin, S.Ag. Pendahuluan

Dosen LB. PKPBA STAIN Malang

Memperbincangkan masalah perempuan memang menarik namun juga menyedihkan. Menarik, karena perbincangan ini berkenaan langsung dengan diri kita sebagai manusia yang secara biologis tercipta sebagai laki-laki dan perempuan. Menyedihkan, karena secara empiris-sosiologis tidak bisa dinafikan akan banyaknya ketidakadilan sosial yang terjadi terhadap gender perempuan.

Ketidakadilan sosial terhadap perempuan ini barangkali merupakan ketidak-adilan sosial tertua dalam sejarah kemanusiaan. Tetapi ketika kita membincangkan masalah kaum perempuan ini dengan analisis gender, sering kali kita

Saiful Amin, S.Ag. Lahir di Tuban, 11 Maret 1974. Menyelesaikan Sarjana S1 di Fakultas Tarbiyah UMM (1999). sebagai dosen LB PKPBA STAIN Malang. Aktif menulis pada majalah-majalah. menghadapi perlawanan (ressistance) baik dari kalangan kaum laki-laki maupun perempuan sendiri. Ini disebabkan karena Pertama, mempertanyakan status perempuan pada dasarnya adalah mempersoalkan sistem dan struktur yang sudah mapan. Kedua, banyak terjadi kesalahpahaman tentang mengapa masalah kaum perempuan harus dipertanyakan? Kesulitan lain, dengan mendiskusikan soal gender pada dasarnya berarti membahas hubungan kekuasaan yang sifatnya sangat pribadi, yakni menyangkut dan melibatkan individu kita masing-masing serta menggugat privilege yang kita miliki dan sedang kita nikmati selama ini.

Meski banyak perlawanan, tetapi justru di situlah letak pentingnya pembahasan masalah perempuan dan keperempuanan ini. Usaha memahami perempuan berarti usaha memahami masyarakat, bagaimana masyarakat terorganisir. Karena perempuan tidak terlepas dari sistem sosial di mana mereka menjadi bagian. Nilai-nilai yang melekat pada perempuan atau keperempuanan merupakan konstruksi sosial yang melibatkan berbagai kekuatan. 
Banyak faktor yang menjadi penyebab munculnya ketidak adilan tersebut.

Diantaranya, menurut sebagian besar feminis adalah karena pembedaan (atau perbedaan?) gender. Sebenarnya pembedaan gender tidaklah merupakan masalah selama tidak melahirkan ketidak adilan gender.
Ketidak-adilan gender terhadap perempuan

Menurut Mansour Fakih, ada 5 fenomena ketidakadilan sosial terhadap perempuan, yang merupakan manifestasi dari ketidak-adilan gender (gender inequilities). Pertama, marginalisasi perempuan baik di rumah tangga, tempat kerja, maupun di masyarakat atau kultur bahkan negara. Proses marginalisasi ini berakibat pada pemiskinan ekonomi perempuan.

Kedua, subordinasi terhadap perempuan karena adanya anggapan gender yang salah. Seperti anggapan bahwa perempuan itu irasional atau emosional sehingga perempuan tidak bisa tampil memimpin, sehingga berakibat kepada munculnya sikap yang menempatkan perempuan pada posisi yang tidak penting.

Ketiga, streotipe yang merugikan kaum perempuan. Seperti adanya asumsi bahwa perempuan bersolek adalah untuk memancing perhatian lawan jenisnya, sehingga setiap ada kasus kekerasan atau pelecehan seksual yang disalahkan adalah pihak perempuan.

Keempat, berbagai bentuk kekerasan (violence) yang menimpa perempuan baik fisik maupun psikologis karena adanya anggapan gender yang keliru. Seperti bahwa perempuan lebih lemah dibanding laki-laki, sehingga laki-laki leluasa melakukan tindak kekerasan terhadap perempuan.

Kelima, pembagian kerja secara seksual yang merugikan kaum perempuan. Misalnya perempuan hanya cocok untuk (dengan) pekerjaan domestik, oleh sebab itu tidak pantas untuk melakukan pekerjaan publik seperti laki-laki. Akibatnya perempuan terkurung dalam ruang dan wawasan yang sempit.

Dengan begitu, tanpa harus melalui penelitian yang seksama, setiap pengamat masalah-masalah perempuan dan keperempuanan akan dengan mudah melihat bahwa perempuan sepanjang sejarah peradaban manusia hanya memainkan peran sosial ekonomi-politik yang kecil dibanding laki-laki.

Banyak faktor yang menjadi penyebab munculnya ketidak adilan tersebut. Diantaranya, menurut sebagian besar feminis adalah karena pembedaan (atau perbedaan?) gender . Sebenarnya pembedaan gender tidaklah merupakan masalah selama tidak melahirkan ketidak adilan gender. Namun kenyataannya adalah bahwa pembedaan tersebut telah melahirkan ketidakadilan sosial 
terhadap jenis kelamin perempuan. Dan pembedaan gender ini telah menyejarah melalui proses sangat panjang yang akhirnya dianggap menjadi ketentuan Tuhan, seolah-olah bersifat biologis yang tidak bisa diubah lagi. Sehingga perbedaan gender dianggap dan dipahami sebagai kodrat laki-laki dan perempuan. Di sini ada proses pembentukan citra baku ideologi gender.

Proses pembentukan citra baku ideologi gender ini, menurut Siti Ruhaini Dzuhayatin, dimulai sejak beratus abad yang lalu di saat peradaban manusia ditegakkan berdasarkan prinsip the survival of the fittest. Prinsip ini lebih banyak mempertimbangkan proses fisik sebagai prasyarat penguasaan struktur sosial. Sebagai akibatnya, perempuan yang secara fisik t)dak setegar laki-laki menjadi termarjinalisasi dari sektor "persaingan budaya". Jadi terbentuknya perbedaan gender ini dikarenakan banyak hal, di antaranya dibentuk, disosialisasikan, diperkuat bahkan dikonstruksi secara sosial dan kultural melalui ideologi, aturan-aturan kenegaraan atau ajaran-ajaran keagamaan.

Ketidak adilan gender yang menimpa perempuan inilah kemudian menggugah banyak orang untuk tampil tak terkecuali di negara yang mayoritas penduduknya muslim sebagai "pejuang" keadilan gender bagi kaum hawa atau biasa disebut dengan feminis; dan melahirkan banyak gerakan feminisme dengan berbagai aliran pemikirannya seperti: Femenisme Liberal, Feminisine Radikal, Feminisme Marxis, Feminisme Sosialis dan Ecofeminisme.

Tulisan ini tidak dimaksudkan untuk mendiskusikan tentang aliran-aliran feminisme diatas, tetapi lebih ditujukan pada perdebatan tentang gender dalam wacana teologis tradisi intelektual Islam. Apakah gender laki-perempuain sama (sejajar) atau berbeda? Kalau sejajar, mengapa bisa begitu? Kalau berbeda, dimanakah letak perbedaannya?, dan mengapa harus berbeda?

Sebelum mendiskusikan pertanyaan-pertanyaan di atas, penulis ingin melihat secara sekilas pergeseran -untuk tidak dikatakan perubahan- paradigma gerakan feminisme dalam melihat pola relasi gender di penghujung abad ke-20. Kemudian apakah pergeseran paradigma itu mempunyai pengaruh terhadap wacana teologis feminis Muslim?

\section{Proses}

pembentukan citra

balcu ideologi gen-

der ini, menurut Siti

Ruhaini

Dzuhayatin, dimulai sejak

beratus abad yang

lalu di saat

peradaban manusia ditegakkan

berdasarkan prinsip the survival of the fittest. 
Banyak perempuan yang telah menjadi male clone (tiruan pria) di peradaban modern Barat, yaitu peradaban ekonomi pasar berdasarkan untung rugi, kompetisi, kekuasaan, materi dan eksploitasi. Sumber daya uang, status, dan kekuasaan yang terbatas harus diperebutkan karena kesuksesan di dunia maskulin diukur oleh ini semua.
Pergeseran paradigma feminisme

Ratna Megawangi mencatat antara tahun 1960 dan 1970an, gerakan feminisme di Barat banyak dipengaruhi oleh filsafat eksistensialisme yang dikembangkan oleh Jean-Paul Sartre. Sartre percaya bahwa. manusia tidak mempunyai sifat alami, fitrah atau esensi (innate nature). Eksistensi manusia tergantung pada bagaimana ia menciptakan esensinya sendiri. Karenanya apa yang disebut esensi manusia pada dasarnya adalah socially created, yaitu tergantung dari lingkungan di mana ia berada. Pemahaman ini kemudian diterapkan oleh Simone de Beauvior untuk menolak eksistensi sifat alami wanita dan pria, dimana ia berpandangan bahwa peran perempuan yang bertugas sebagai pengasuh anak dan keluarganya serta memelihara lingkungan hidup bukan karena sifat alamiah perempuan, tetapi merupakan norma-norma feminin yang dikonstruksikan oleh sistem patriarkhi agar perempuan menjadi kelas dua dan dapat terus "ditindas". Beauvior menekankan bahwa perempuan harus melepaskan diri dari norma-norma tersebut agar mereka dapat menentukan eksistensinya sendiri.

Dengan landasan paradigma seperti itu, maka gerakan feminisme Barat pada periode 1960 dan 1970-an diwarnai oleh tuntutan kebebasan dan persamaan hak agar para perempuan dapat menyamai pria dalam bidang sosial, ekonomi dan kekuasaan politik. paradigma ini terepresentasikan pada gerakan feminisme liberal, radikal, maxis dan sosialis. Kini kaum perempuan sudah terlibat sepenuhnya di dalam dunia maskulin dan berkiprah bersama-sama dengan pria. Di balik keberhasilan ini banyak yang mengatakan bahwa para perempuan tidak saja memasuki dunia maskulin tetapi telah sepenuhnya mengadopsi nilai-nilai màskulin yang dulu dikritiknya, serta meninggalkan sikap kepedulian terhadap pengasuhan dan pemeliharaan. Banyak perempuan yang telah menjadi male clone(tiruan pria) di peradaban modern Barat, yaitu peradaban ekonomi pasar berdasarkan untung rugi, kompetisi, kekuasaan, materi dan eksploitasi. Sumber daya uang, status, dan kekuasaan yang terbatas harus diperebutkan karena kesuksesan di dunia maskulin diukur oleh ini semua.

Peradaban manusia modern (baik pria dan wanita) semakin terlihat ingin menguasai, mendominasi, dan mengeksploitasi. Kerusakan alam, polusi, perkosaan terhadap bumi, kriminalitas, 
menurunnya solidaritas sosial dan sebagainya telah menjadi ciri pari peradaban manusia modern itu. Lambat laun banyak eeminis yang semakin sadar bahwa peradaban modern telah pegitu tidak seimbang; terlalu berat pada kualitas maskulin, dan kurang pada kualitas feminin seperti cinta, kepedulian, pengasuhan dan pemeliharaan. Timbullah pemikiran baru untuk inengoreksi kecendrungan ini. Maka pada tahun 1980-an paradigma feminisme telah berbalik, yaitu memuji keunggulan kualitas feminin serta memaksimumkan perbedaan alami antara pria dan perempuan; bahwa secara esensial memang pria dan perempuan berbeda. Kalau sebelumnya kualitas feminin dianggap "inferior" kini bahkan dianggap "superior". Para eminis tersebut mengajak para perempuan untuk melestarikan kualitas feminin agar dunia ini menjadi lebih seimbang dan segala kerusakan yang terjadi dapat dikurangi. Paradigma ini erepresentasikan pada gerakan ecofeminisme, dimana pada tataran sosial telah memberi nilai lebih tinggi pada kualitas feminin dari pada kualitas maskulin. Sehingga akibatnya justru gerakan ecofeminismeini terjebak pada penciptaan pola hirarkis baru bahwa (seakan) kualitas feminin berada di puncak kebenaran. Pertanyaan yang perlu diajukan sekarang adalah bagaimanakah pemikiran teologis para feminis muslim dalam inemandang relasi gender laki-laki dan perempuan?

Wacana teologi feminis muslim

Karena pembahasan ini bersifat teologis-normatif maka untuk melihat bagaimana relasi gender laki-laki dan perempuan dalam perspektif para feminis Muslim, kita perlu merujuknya kepada interpretasi mereka terhadap sumber utama Islam, yakni ayat-ayat al-Qur'an dan Sunnah Nabi SAW. yang berkenaan rentang gender dan relasinya. Dalam hal ini banyak ulama lerdahulu dari berbagai tradisi intelektual Islam telah memberikan penafsirannya.

Dalam tradisi Islam dikenal dan diyakini ada 4 macam cara penciptaan manusia, yaitu : Pertama, diciptakan dari tanah (penciptaan Adam AS.). Ini merujuk pada surat Fathir 35:11; L-Shaffat 37: 11; dan al-Hijr 15:26. Kedua, diciptakan dari tulang rusuk Adam (penciptaan Hawa). Ayat yang dijadikan rujukan adalah surat al-Nisa ' 4: 1;al-A'jaf 7: 189 dan al-Zuninar 39:62Ketiga, diciptakan melalui seorang ibu dengan proses kehamilan tanpa
Pertanyaan yang perlu diajukan sekarang adalah bagaimanakah pemikiran teologis para feminis muslim dalam memandang relasi gender lakilaki dan perempuan? 
Oleh sebagian feminis muslim dewasa ini, penafsiranpenafsiran itu dianggapnya bersifat bias lakilaki, sehingga memberikan pemahaman teologis yang kelinu tentang gender, dan menurut mereka justru memberikan andil sebagai justifikasi ayah, baik secara biologis maupun secara hukum (penciptaan nabi Isa AS). Surat Maryam 19:19-22. Dan keempat, diciptakan melalui kehamilan dengan adanya ayah secara biologis dan hukum, atau minimal secara biologis semata (penciptaan manusia selain Adam, Hawa dan Isa ). Surat al-Mukminun 23:12.

Berbeda dengan ketiga macam cara penciptaan yang lain, ayat-ayat yang menjelaskan tentang penciptaan Hawa tidak menyebutkan secara jelas dan terperinci mekanisme penciptaan Hawa, sehingga sangat potensial untuk menimbulkan banyak interpretasi yang kontroversial.

Dalam ketiga ayat di atas (QS. al-Nisa' 4:1; al-A'raf 7:189 dan al-Zumar 39:6) (QS. al-Nisa ' 4:1; al-A'raf 7:189 dan al-Zumar 39:6), tidak disebutkan secara eksplisit nama Adam dan Hawa, tapi diungkapkan dengan kata nafs wahidah dan zawjaha. Para mufassir kemudian mengambil ayat-ayat lain (seperti QS. alBaqarah 2: 30-31, al-A'raf 7:27) dan hadits-hadits Nabi sebagai bantuan untuk memahami maksud kata nafs wahidah dan zawjaha tersebut. seperti hadits Nabi : "Perlakukanlah perempuan dengan baik, karena perempuan diciptakan dari tulang rusuk yang paling bengkok adalah bagian yang paling atas, maka jika kalian mencoba untuk meluruskannya, ia akan patah, tapi jika kalian membiarkannya sebagaimana adanya, ia akan tetap bengkok. Maka perlakukanlah perempuan dengan baik." (HR.Bukhari) Dari sini mereka memastikan dan menyakini bahwa yang dimaksud dengan kata pertama dalam ayat-ayat di atas adalah nabi Adam AS. (Laki-laki) dan kata kedua adalah istrinya, Hawa.

Oleh sebagian feminis muslim dewasa ini, penafsiranpenafsiran itu dianggapnya bersifat bias laki-laki, sehingga memberikan pemahaman teologis yang keliru tentang gender, dan menurut mereka justru memberikan andil sebagai justifikasi teologis dalam melanggengkan dominasi laki-laki atas perempuan, terutama tafsir ayat-ayat Quran dan hadits Nabi yang berkenaan dengan proses penciptaan perempuan di atas. Oleh karenanya penafsiran-penafsiran ini, bagi mereka, perlu ditolak. Para feminis muslim, seperti Asghar Ali Enginer contohnya, mengkritik dengan tajam metode penafsiran yang memahami nash hanya semata-mata bersifat normatif dengan mengabaikan pendekatan sosiologis.

Berbeda dengan pandangan para feminis muslim di atas, 
ada sebagaian cendekiawan muslim yang mendukung dan membenarkan penafsiran ulama-ulama terdahulu terhadap nash qur'an dan Sunnah tentang gender. Kelompok kedua ini percaya para ulama terdahulu itu sebagai muslim yang tulus, yang menempatkan Tuhan di atas segalanya, sehingga mereka dianggap mempunyai otoritas dalam menafsirkan nash. Ini dilakukan karena mereka tidak mau gegabah dalam menafsirkan nash. Mereka tidak sependapat dengan seorang feminis yang mengatakan bahwa siapapun bisa menafsirkan al-Qur'an dan hadits menurut pemikirannya masing-masing, termasuk dirinya. Mereka khawatir ini akan membuat manusia menganggap agama dapat dipakai sebagai alat untuk melegetimasi agendanya yang dapat diubah-ubah tergantung kepentingannya.

Adanya dua pandangan yang saling berseberangan dalam menyikapi penafsiran nash Qur'an dan Hadits mengenai gender oleh tradisi intelektual Islam terdahulu ini, menurut hemat penulis disebabkan karena pendekatan dan metode yang dipakai oleh kedua kelompok tersebut berbeda.

Kelompok pertama mendekati nash secara lahiriah dan menginginkan nash Qur'an dan hadits ditafsirkan dengan cara historis-kontekstual bi al-Ra yi. Sehingga, dengan begitu mereka menolak penafsiran tradisi intelektual Islam terdahulu yang secara lahiriah (fiqhiyah dan kalamiah) terkesan merendahkan gender perempuan.

Sedangkan kelompok kedua, mereka mempergunakan metode tafsir bi al-Ma'tsur, dan dalam mendekati nash mereka menganjurkan untuk tidak terpaku pada penafsiran lahiriah etapi hendaknya terus merasuk pada makna batiniah. Sehingga mereka cenderung membenarkan penafsirkan tradisi intelektual slam klasik terhadap ayat (QS. 4:1, 7:189, 39:6) dan hadits yang menjelaskan tentang proses penciptaan perempuan di atas. Karena proses penciptaan perempuan seperti itu menyiratkan hikmah batiniah adanya cinta dan perkawinan yang mempunyai kesesuaian kosmis dengan alam. Bahwa laki-laki cenderung cinta dan gandrung kepada perempuan karena secara alamiah la menyadari perempuan merupakan bagian dari dirinya, begitu fuga sebaliknya perempuan cinta dan cenderung kepada lakiaki karena ia sadar bahwa laki-laki merupakan muasal dirinya. Dengan begitu mereka akan mewujudkan tanggungjawab perkawinan (tazawwuj: berpasangan) yang saling menyatu dan
Bahwa laki-laki cenderung cinta dan gandrung kepada perempuan karena secara alamiah ia menyadari perempuan merupakan bagian dari dirinya, begitu juga sebaliknya perempuan cinta dan cenderung kepada laki-laki karena ia sadar bahwa laki-laki merupakan muasal dirinya. 
Kalau laki-laki berwarna hitam, perempuan harus

berwarna beda, putih umpamanya, keduanya bersatu dan saling melengkapi menjadi warna yang polar abu-abu. Atau dengan bahasa ieologi, kesatuan antara sifat Tuhan jamal (Yin, feminitas) dengan sifat Tuhan Jalal (Yang, maskulinitas) sehingga terusujudlah sifat Tuhan kamal (sempuma). melengkapi. Sebagaimana perkawinan makrokosmis yang saling menyatu dan menyeimbangkan dalam harmoni antara langit (maskulin) dan bumi (feminin), antara siang dan malam, dan sebagainya.

Dari uraian di atas, penulis melihat wacana teologi para feminis muslim di masa datang paling tidak diwarnai dua pola gerakan feminisme yang lahir dari kedua madzhab pemikiran teologis di atas:

Pertama, gerakan feminisme Islam yang memperjuangkan keadilan gender dengan berusaha menyamakan (mensetarakan) antara laki-laki dan perempuan fifty-fifty. Bagi feminis ini dalam bidang seks laki-perempuan boleh berbeda, tetapi di bidang gender keduanya harus sama dan setara, karena gender merupakan hasil konstruksi sosial budaya masyarakat (nurture). Di sini nampaknya ada pengaruh paradigmatis, untuk tidak mengatakan mengkopy, Feminisme Barat tahun 1960 dan 1970an, terutama oleh pemikiran madzhab orientasi kultur (culturallyoriented contestants). Asumsi (ide) dasar yang diperjuangkan adalah bagaimana perempuan dan laki-laki bisa sama sejajar 50/50 dalam satu warna; laki-laki putih perempuan juga putih, laki-laki hitam perempuan juga sama seperti itu.

Pola kedua, Gerakan feminisme Islam yang memperjuangkan keadilan gender dengan berusaha menjelaskan bahwa perempuan dan laki-laki di bidang gender -seperti seksbagaimanapun tetap berbeda. Perbedaan ini bersifat "given" alamiah (nature). Perbedaan ini tidak untuk saling mengeksploitasi (mendominasi) dalam sebuah relasi yang hirarkhis, tetapi untuk saling menyatu dan melengkapi. Ide dasar yang diperjuangkan adalah kesatuan dan keseimbangan antara nilai maskulinitas dan nilai feminitas dengan polaritas warna yang harus berbeda. Kalau laki-laki berwarna hitam, perempuan harus berwarna beda, putih umpamanya, keduanya bersatu dan saling melengkapi menjadi warna yang polar abu-abu. Atau dengan bahasa teologi, kesatuan antara sifat Tuhan jamal (Yin, feminitas) dengan sifat Tuhan Jalal (Yang, maskulinitas) sehingga terwujudlah sifat Tuhan kamal (sempurna). Nampaknya pola kedua ini juga dipengaruhi secara paradigmatis oleh gerakan Ecofeminisme. yang muncul tahun 1980-an, terutama oleh pemikiran madzhab esensial biologis (biologically oriented 
contestants) yang kemudian dikolaborasikan dengan pemikiran kosmologi Islạm.

\section{Penutup}

Dengan demikian, wacana teologi perempuan dalam Islam, paling tidak implikasi sosialnya akan diwarnai oleh tarik ulur antara perjuangan "menyamakan" (menyejajarkan) gender laki-perempuan di satu sisi dan perjuangan "menyatukan" keduanya dalam keharmonian kosmis di sisi yang lain.

Yang pertama berusaha menghilangkan ketidak-adilan sosial yang menimpa perempuan dengan mengangkat eksistensi gender perempuan agar bisa sama dan setara dengan pria. Sedangkan yang kedua berusaha menghilangkan ketidak adilan sosial itu dengan mempertegas, untuk tidak mengatakan mengangkat,ke-berbeda-an gender perem-puan agar bisa saling menghormati dan melengkapi dalam kesatuan alamiah. Wa $A$ lah alam! 


\section{DAFTAR PUSTAKA}

Abdullah (Ed.), Irwan, "Pengantar" dalam Sangkan Paran Gender, Pustaka Pelajar, Yogyakarta, 1997

Bainar (Ed.) et. al., "Pengantar Editor"dalam Wacana Perempuan dalam Keindonesiaan dan Kemodeman, Pustaka Cidesindo, Jakarta, 1998

Budiman, Arif, Pembagian Kerja Secara Seksual, Sebuah Pembahasan Sosiologis Tentang peranan Wanita di dalam Masyarakat, PT Gramedia, Jakarta, 1982.

Echols, John M., dan Hassan Shadily, Kamus Inggris-Indonesia, PT. Gramedia Pustaka Utama, Jakarta.

Enginer, Asghar Ali, "Perempuan dalam Syari ah: Prespektif Feminis dalam Penafsiran Islam" dalam Jumal Ulumul Qur'an, No.03 vol.VTahun 1994

- Hak-Hak Perempuan dalam Islam, terj. Farid Wajdi, Bentang Budaya, Yogyakarta, 1994

Fakih, Mansour, Analisis Gender dan Transformasi Sosial, Pustaka Pelajar, Yogyakarta, 1997

Ilyas, Yunahar, Feminisme dalam Kajian Tafsir al-Qurán Klasik dan Kontemporer, Pustaka Pelajar, Yogyakarta, 1997

Megawangi, Ratna, Membiarkan Berbeda?, Mizan, Bandung, 1999

Murata, Sachiko, The Tao of Islam, Mizan, Bandung, 1992 